测定法と語算法は良好な相関を示した。

【考察】モンテカルロ法を利用したソフトウエアは, 患者入射面の線 量を必要な精恔で推定できると考えられた。モンテカルロ法の利用 した方法は，照射野内の入射表西線量だけでなく，撮影照射野外(線 束外)の臟器の平均吸收線量の事前推計も可能である。医療被曝の適 正化を図るには，入射表百線量だけでなく主要臓器の等価線量の把 握が重要であると考える

\section{0 思者からの敬乱線の評価}

名古屋大学大学院 秋田経理

名古屋大学・保健学科 田宮 正, 田伏勝義，津坂昌利，小山修司

【目的】近年，IVRなどの高線量率透視の際，散乱線と考えられる術 者の被睅事例が派告されている。 そこで, 患者から発生する散乱線 の性:状について恰討し, 被爆低減対策の資料を得る目的で, 一次X 線に対する散乱線の線量およびエネルギースペクトルをモンテカル ロシミュレーションと実测実験を行い, シミュレーションの妥当性 について検討した。

【方法】今回使玔したモンテカルロ計算コードは高エネルギー加速器 破究機構 (KEK) から提供されているEGS 4 (Electron GAMMA SHOWER) 使用した。また本研労では，低エネルギーX線を対象と しているため, EGS 4 を低エネルギーに拡張するLSCATを含むKEK 搪張版を使用した。モンテカルロ計算コードのジオメトリは SSD $100 \mathrm{~cm}$ で, 照射野は $5 \mathrm{~cm} \times 5 \mathrm{~cm}, 10 \mathrm{~cm} \times 10 \mathrm{~cm}, 20 \mathrm{~cm} \times 20 \mathrm{~cm}$ で, 水ファントムは $20 \mathrm{~cm} \times 30 \mathrm{~cm} \times 30 \mathrm{~cm}$ と， 入射スペクトルは啭測に使 㸝した次線スペクトルと一致するスペクトルをBirchらの式を使っ て求め人射させ，側方敬乱の性質を算出した。測定のジオメトリ はシミュレーションと同様で, スペクトルの測定にはhpGe倹出器を 用い，線量の测告には電離箱線量訢とガラス線量計を用いた。

【結果抢よび考察】实測とシミュレーションとの比較であるが散乱線 のエネルギースペクトルはほぼ一致し，また平均エネルギーで比べ

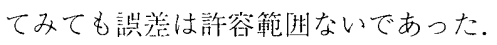

261 モンテカルロシミュレーションを用いた一般撮影時の人体線 量分布計算の検討

金沢大学 医学部保健学科放射線技術科学専攻 桑村啓太

金沢大学大学院・医学系研究科 能登公也

金沢大学 医学部保健学科 越田吉郎

【日的】垷在，一般撮影時における患者の被曝は入射表面線㻎で評価 されている。しかし, 箺効線量で評㑣する埸合, 各蔵器組織の吸収 線畫を求める必要がある。そこで，モンテカルロ法(EGS4)により人 体ファントム内の線量分布を解析することによりその有用性につい て検討した。

【方法】モンテカルロ計算コードEGS4 (ucphantom_rec1 mor)を用い て，アクリルファントム内の照射野中心拉よび照射野外に扔ける深 部線量分有を計算した，その後，水ファントムとの比較を行った。

また，TLDを用いて比較検討した，X線のスペクトルはBurchらの式 を用いた。

【結果】照射野中心に扔いては，吸収線量は指数関数的に減少する。 照射野外においては，わずかに増加し，その後減少する。

【考察】モンテカルロ法を用いた線量分胍のシミュレーションは，人 休内線量分有㧍よび各臟器組織への吸収線量を求める手段として有 用であると示唆される。
262 モンテカルロシミュレーション用数学ファントムの構築-CT データに基づくボクセルファントムの作成 -

藤田保健衛生大学・衛生学部南一幸。江尻和隆，下道國 藤田保健衛生大学病院 放射線部 加藤正基, 竹内吉人

藤田保健衛生大学坂文種報徳會病院 放射線科 米持圭太

聖隷浜松病院・放射線部 水田真一

【目的】人体内での放射線被曝の詳細を知るには人体モデルに対する モンテカルロシミュレーション法が用いられる。しかし，その精度 はモデルの構築に拀いて人体をどこまで正確に再現するかに依存し て扔り，人体モデルではそれを評価することは容易でない。そこ で, 実測值と対比し，その精度が検討できるモデルとして人体ファ ントムの数学ファントム(ボクセルファントム)化を試みた。

【方法】人体ファントムとしてファントム・ラボラトリー社製ランド ファントムRAN-100型を使用し，東芝製X線CT装㯰Aquilınにて撮 影した画像データからシミュレーション用ボクセルファントムを作 成した。ボクセルファントムは，ファントムの構成要素である贤，

肺, 軟部組織, アクリル, 倹出器挿入部 (MIX DP)などに領域分け し、ボクセルサイズは $3.6 \times 3.6 \times 5 \mathrm{~mm}(128 \times 128$ pixels, $5 \mathrm{~mm} / \mathrm{sl}$ ice $)$ と した。線量評価のためのモンテカルロ訪算コードには, Electron Gamma Shower version 4(EGS 4)を用い，シミュレーションの試み として数種の光子エネルギーに扔ける線量分布を算出した。

【結果と考察】シミュレーションで得られたボクセルファントムの線 量分布は，検討したどの光子エネルギーに抢いてもその微練構造を 詳細に表現し，実測值との比挍が可能と考えられた。

【結論】人体ファントムの数学ファントム化は, 線量の实測とシミュ レーションとの対比を可能にし，今後の人体モデルの情筑に多くの 情報を与えうる。

263 低エネルギー光子対心型蛍光ガラス線量尌用フィルタの設計 ーモンテカルロ計算コードを用いた方法ー

藤田保健衛生大学 衛生学部 江尻和隆, 南一幸, 下道國 藤田保健衛生大学病院·放射線部 寺田桂子, 前田繁信, 竹内吉人 藤田保健衛生大学坂文種報徳會病院 放射線科 米持圭太，加藤彰子 （株）千代田テクノル 諏訪儀行

【目的】昨年，実效線量， $1 \mathrm{~cm}$ 線量当量等が直接測定できる蛍光がラ ス線量計用フィル夕(錫製)の閉発を試み，モンテカルロ法によりこ れらの線量を直接測定できるフイル夕の設計に成功した。しかし， このフィル夕には錫のK吸収( $29 \mathrm{keV})$ に起因する不連続なエネルギー 特性があり，測定対象光子は $0.03 \sim 1 \mathrm{MeV}$ の籁間に限定された。 そ こで, 診断用X線領域での利用を考慮し, フィル夕の材料にアルミ ニウムと銅を追加することで, 測定範困を低エネルギ一側に搪張す る方法を試みた。

【方法】蛍光ガラス線量計のモデルとして，(株)旭テクノグラス製 Dose AceのGD-300シリーズを用いた。フィル夕の材質にはアルミニ ウム，銅，錫を採用し，まず，それぞれの材質でできた均一なつィ ルタモデルを作製し，その厚みを徐々に変化させたときの線量計の 光子エネルギー吸收特性 $(0.01 \sim 10 \mathrm{MeV}$ 範团)を，モンテカル口計算 コードEGS 4 を用いて求めた。次に, これらの特性から不連続な特 性を排除し, 残りの特性の荷重和加, 実効線量, $1 \mathrm{~cm}$ 線量当量へ の換算係数に近似する特性を作成し，このとき得られた少重係数に 従って実用型フィル夕を設計した。さらに, 設計したシステムのエ ネルギー吸収特性を再びEGS4で求め, 目的とする特性に近似するか 確認した。

【結果】設計したフィルタは拉よそ15keVから120keVの範囲で实効線 量や $1 \mathrm{~cm}$ 線量当量の特性に良く近似し，優れた特性を示した。

【結論】フィルタの材質にアルミニウム，銅，錫を組み合わせること により，実効線量， $1 \mathrm{~cm}$ 線量当量の测定対象エネルギー下限を $15 \mathrm{keV}$ まて搪張できた。 